[5].Busurin, V. I, Nosov, Yu. R. (1990). Volokonno-opticheskiye datchiki: fizi-cheskiye osnovy, voprosy rascheta i primeneniya. [Fiber-optic sensors: physical foundations, issues of calculation and application]. -Moscow: Energoatomizdat, - 256 p. [in Russian].

[6].Snyder A., Love D. (1987). Teoriya opticheskikh volnovodov. [Theory of optical waveguides]. - Moscow: Radio i svyaz'. [in Russian].

[7].Sandler, A. K. (2020). Optymizatsiya konstruktyvnykh parametriv volokonnoho akselerometru. [Optimization of design parameters of the fiber accelerometer]. Bratislava: Slovak international scientific journal. - № 42. VOL.1. - P. 25-31. [in Slovak].

[8].Sandler, A. K. (2021). Metod pidvyshchennya efektyvnosti diahnostuvannya tekhnichnoho stanu sudnovykh hazoturbinnykh ustanovok na osnovi volokonno-optychnykh tekhnolohiy [Method of improving the efficiency of diagnosis of the technical condition of ship's gas turbines plants based on fiber-optical technologists]. Kyiv [in Ukraine].

[9].Sandler, A.K. (2019). Chuvstvitel'nyy element volokonno-opticheskogo akselerometra na osnove sapfirovogo stekla. [Sensitive element of a fiber-optic accelerometer based on sapphire glass]. Odessa: IX international scientificmethodical conference "Ship`s electrical engineering, electronics and automation". [in Ukraine].

[10]. Sandler, A. K. (2019). Modelirovaniye akselerometra mayatnikovogo tipa. [Modeling of a pendulum-type accelerometer]. Cherkasy: Bulletin of the Cherkasy State Technological University. -No. 1. - P. 75 - 81. [in Ukraine].

[11]. Sandler, A. K, Logishev, I. V., Sandler, A. A. (2011). Ynvaryantnyy volokonnyy akselerometr. [Invariant fiber-optic accelerometer] // Ship energy: operation and repair: materials of scientific and technical conference. - Odessa: ONMA. P. 277-279. [in Ukraine].

Отримана в редакції 30.06.2021. Прийнята до друку 23.08.2021. Received 30 June 2021. Approved 23 August 2021. Available in Internet 31 September 2021.

\title{
IMPLICATIONS OF UNIVERSITY-BUSINESS COOPERATION \\ FOR HIGHER EDUCATION IN A TIME OF CYBERNETICS: EMERGING TRENDS AND DILEMMAS
}

\author{
Tarasevich I.G. ${ }^{1}$, Tarasevich A. ${ }^{2}$ \\ ${ }^{1}$ National Metallurgical Academy of Ukraine, Dnipro, Ukraine \\ ${ }^{2}$ The University of Western Ontario, London, Ontario, Canada \\ ORCID: ${ }^{1}$ 0000-0002-3249-619X, ${ }^{1}$ 0000-0003-0798-0569 \\ E-mail: ${ }^{1}$ tig-app@ukr.net, ${ }^{2}$ atarasev@uwo.ca
}

Copyright (C) 2021 by author and the journal “Automation of technological and business - processes”.

This work is licensed under the Creative Commons Attribution International License (CC BY).

http://creativecommons.org/licanses/by/4.0

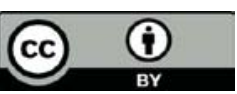

DOI:

"You're either the one that creates the automation or you're getting automated”.

-Tom Preston-Werner, an American billionaire, software developer and entrepreneur

Abstract. Universities and business collaborate for their own ends that do not necessarily match. While the industry is always profit-driven and practice-oriented with primarily short-term goals in mind, the university focuses on strategic planning, theory development, and long-term goals. University-business collaboration (UBC) has diverse modes or activities 
among which the most common are: 1) research and development (R\&D); 2) mobility of academic staff; 3) student mobility; 4) curriculum development and delivery; 5) lifelong learning. While the focus of UBC is on conducting practice-oriented research, each university and enterprise have their own unique combinations of activities that reflect their goals and needs. All the five collaborative research activities demonstrate different effects with UBC drivers, barriers, and organizational characteristics that are further explored in the article.

Similar to automation, higher education is in many ways a stochastic adaptive control system, the behaviour of which depends on parameters with unknown values. The system has to perform in order to collect specific values of these parameters. The values are crucial as, once collected, they can be used to alter the system's performance. Following this logic, we consider the five modes specified above as key UBC parameters, put in their emerging trends as parameters' values, and consider emerging dilemmas and implications for higher education. The key challenge nowadays is around the adaptability of higher education. More than ever before, educators around the world grapple with the idea of whether and how adaptive the modern university should be to the business world needs in the context of global automation. This article is our attempt to add to a meaningful debate around this topic.

Анотація. При співпраці університет і бізнес переслідують свої власні иілі, які не обов'язково збігаються. У той час як галузь завжди орієнтована на отримання прибутку і орієнтована на практику, маючи на увазі в першу чергу короткострокові цілі, університет приділяє особливу увагу стратегічному плануванню, розвитку теорії $i$ довгостроковим иілям. Співпраця між університетом і бізнесом (UBC) має різні форми або види діяльності, серед яких найбільи поширеними є: 1) дослідження і розробки (R \& D); 2) мобільність професорсько-викладацького складу; 3) студентська мобільність; 4) розробка і викладання навчальних програм; 5) навчання протягом усього жсття. У той час як співпраця між університетами та бізнесом (UBC) зосереджена навколо проведення досліджень, орієнтованих на практику, кожен конкретний ВНЗ і підприємство створюють свою модель співпрачі з тими видами спільної діяльності, включаючи запропоновані вище п'ять видів спільної діяльності, які максимально відображають їх власні ияілі і потреби. Кожен з п'яти спільних видів діяльності ефективний по-своєму і має певний набір факторів, щзо стимулюють або, навпаки, ускладнюють їх розвиток, про щзо мова піде більш детально в даній статті.

Подібно автоматизації, вища освіта багато в чому є стохастичною адаптивною системою управління, поведінка якої залежить від параметрів з невідомими значеннями. Система повинна працювати, щзоб збирати конкретні значення ичи параметрів. Значення грають важливу роль, оскільки після отримання системою вони можуть використовуватися для зміни продуктивності самої системи. За такою логікою ми розглядаємо п'ять режимів, зазначених вище, як ключові параметри UBC, застосовуємо їх нові тендениії в якості значень параметрів $i$ розглядаємо дилеми $і$ наслідки, щзо виникають, для вищої освіти. Сьогодні основна проблема пов'язана з адаптованістю вищої освіти. Як ніколи раніше, викладачі в усьому світі задаються питанням, наскільки адаптивним повинен бути сучасний університет до потреб ділового світу в контексті глобальної автоматизації. Ця стаття наша спроба додати до змістовної дискусії на ичю тему.

Key words: university-business collaboration (UBC), automation, research and development (R \& D), academic mobility, student mobility, curriculum development, curriculum development, UBC drivers.

Ключові слова: співробітництво між університетом і бізнесом (UBC), автоматизація, дослідження та розробки (НДДКР), академічна мобільність, студентська мобільність, розробка навчальних планів, розробка навчальних програм, драйвери UBC.

Introduction. The current technological processes are changing what it means to be human. We now access big data that can tell us new things and enable machines to do them. Many current jobs are either automated or automatable. And the process of automation is under way, so only time will tell us how many and in what areas. A pillar of contemporary development, automation is present - physically, tangibly and inevitably - in every aspect of human activity and transforms it. Higher education is no exception. More so, it is an area in which the change, as well as opportunities and challenges it brings on, are very real, almost palpable on societal skin. It is through the lens of automation, an important anchor for the discussion, I will be looking at what is happening in higher education and why. Where possible and to illustrate the points being made, I will provide real-life examples.

University education worldwide is undergoing rapid changes with far reaching implications both for educators and students. What are they? The market place is getting increasingly competitive. Humankind is experiencing the Fourth Industrial Age ( $4^{\text {th }}$ IA): big data and artificial intelligence blend to bring about automation literally in every field of human activity - from the internet of things to astrophysics explorations. Physical and cyber worlds are fused together in most intricate ways and on a most massive scale. The challenging goal of higher education is to prepare for an uncertain future. It can be best achieved via an integrated scholarship when pedagogical approaches are continuously appraised for their sustainability [1]. Students, universities, employers and wider society - all have expectations. The biggest challenge of higher education is to ensure that the pedagogical approaches-in-use are aligned with these expectations, present and future ones.

Main Part. An Overview of the Fourth Industrial Age: Its Challenges and Opportunities.

To say the least, people are living in a rapidly changing technological time. As Schwab (2017) aptly put it, people live in a time of great promise and great peril [2]. The promise is in connecting people around the world, sharing knowledge and regenerating the natural environment. The peril, however, lies in further societal fragmentation and growing inequalities, with automation dominating and people questioning their role of humans. 
The development of education is, to some extent, similar to the development of industry [3]. When applied to automation, higher education can be compared to a stochastic adaptive control system: unknown parameters of a control system are modelled as random processes or variables [4]. The general approach to adaptive control is about separating parameter identification and adaptive control [4, p. 769]. How a control system behaves, depends on a set of parameters with unknown values. The values of these parameters remain unknown until the system performs and only then some crucial information is collected that, in turn, is used to alter the system's performance. Until then the control system remains to be 'a black box' to the controller.

Similarly, education is a stochastic process that is characterized by a lot of noise in the system but also by some degree of consistency [4, p. 775]. It is a process with a number of variables: vision, design, data collection and analysis [4, p. 776]. Educators get to know their trainees and each time they teach a course, they necessarily adapt it to a particular cohort of students. With every class, they collect and analyze data, build a portfolio, and enhance their teaching. As a result, the course is refined, with the best pedagogical approaches being implemented, while systematically replacing the weakest elements. It is what Boyer (1990) defines as scholarship in teaching when the work of an educator becomes meaningful only when it is understood by others [5].

On an institutional level, universities need to adapt to changes caused by the rapid development of technology, in general, and automation, in particular. Their ability to do so will largely shape future educational landscape that is yet unknown. What is clear, however, is that university education will become increasingly 'virtual' (internet-based), international and interdisciplinary (for convenience, I personally call it 'education of three 'I's). University education has already shifted and will continue its shift from being available to the privileged few to the masses. In other words, 'elite' higher education will become 'mass' education for everybody who might be interested.

Another key challenge that higher education faces today is an urge to preserve the link between professional training and work. Peters, Jandrić \& Means (2019) conducted a review of recent policy documentation about the future of work and suggested three possible scenarios: 1) a worst-case scenario of full joblessness; 2) a business-as-usual scenario; and 3) a hybrid scenario of human control over augmented and artificial intelligencies [6]. In an era of widespread automation, people are concerned about the function and purpose of education as such. If labour no longer exist as a political category and a set of processes, the authors (Peters, Jandric, \& Means, 2019) speculate the following four responses [6]. The first response is based upon 'third' sector' (aka 'the voluntary sector') expansion that covers a wide range of organizations that are neither public nor private. Among them are non-governmental, not-profit, and values-driven organizations. The second possibility is a conventional business model. The third response is focused on technologies augmenting the human role rather than replacing them. Finally, the fourth possibility is than the linkage between work and education is irreversibly broken, something we do not want to go into. That is why meaningful social debates are necessary in imagining drastically different relationships between work and education.

Given the unknown future described above, university graduates must be adaptive and self-directed in their thinking and learning. These days, the shelf life of any skill has become notoriously short which requires educators, trainees and experts to continuously upgrade their skill set and become lifelong learners. They need to familiarize themselves with ever-more complex industries and technologies that may not have been in existence at the time of their training for initial degrees. Graduates can and should use different pathways to re-connect with their institutions as this will provide them with updated skills.

The faculty and students should be regularly exposed to workplace realities within corporate and industrial sectors. For instance, Stanford University has launched the Stanford2025 project with several mechanisms whereby students can extend their education over a longer period of time [7]. One of the models is the "open loop university”: students can spend six years on higher education over their entire adult careers. This can allow them to refresh their toolbox of skills while being on campus and to blend their learning with real-life experience. They also provide value to the campus community by returning as expert practitioners over several intervals.

With rapid change and exponential growth being the hallmark of the $4^{\text {th }}$ IA, it is imperative for universities to update their course load content very often so that universities can compete with the tempo of technological advances. By definition, curriculum has to be extremely responsive that places a high premium on faculty development [8]. University staff are expected to work at the cutting edge of their respective fields and universities are considered to be "ideal entrepreneurial ecosystems" [9]. Consequently, students have ample opportunity to be exposed to as well as to actively engage with the frontiers of knowledge. The ultimate goal of this gigantic work is to develop future experts who can think and redefine themselves in the rapidly emerging environment.

\section{General European trends in UBC.}

In our literature analysis, we purposefully review executive summaries, national reports and case studies summaries prepared for the European Commission. These are collaborative international research projects that embrace a wide range of European countries [10]. For data collection and analysis, they used two complementary approaches - in-depth case studies (quantitative research methods) and workshops (qualitative research methods). While in-depth case studies, in the form of questionnaires, collected structured, statistically significant data, workshops allowed rich, thick data via discussions and experience sharing on a variety of UBC-related topics between the business sector and the scientific community. The design of workshops aimed at offering different perspectives across workshop sessions [10]. The phenomenon of UBC is so complex and multifaceted that conducting solely quantitative or qualitative research cannot capture the richness and the complexity of the topic at hand. That is why we consider the mixed methods approach to be most appropriate for our research question. The 
overarching question that informs our inquiry is whether cooperation between private sector organizations and universities is a real partnership or more of a corporate social responsibility. We try to explore each phenomenon of interest from two distinct perspectives - from university's perspective and from business perspective.

UBC is still at an early stage of its development in Europe: as much as 40 per cent of faculty members are not involved in UBC at all; approximately 20 per cent of them participate in UBC at a low extend; and another 40 per cent of academia are actively engaged in UBC [11]. The low percentage of UBC engagement can be partially attributed to what Davey et al. (2018) label as 'university influence': the greater the number of years that the faculty teach, the less likely they are to cooperate with business. Although those engaged - both from academia and business - primarily collaborate in research, each has their own combination of specific UBC activities (the faculty/industry focus, according to Davey et al., 2018) [12].

When looked at the modes of cooperation by size of the enterprise, micro businesses (1 to 10 employees) do not participate in R\&D and academic mobility. More involvement is seen from small and medium-sized enterprises (SMEs - 12 to 250 employees) and large enterprises (with 251 employees and over) enjoy the most engagement into UBC activities. Such a state of affairs is almost common sense as micro companies do not have enough capacity (financial, human, scientific, etc.) to invest heavily into many UBC activities whereas large corporations have deep pockets and resources to do so [13]. When types of UBC interaction are further analyzed by sectors (industry, service, and IT), service and IT sectors have much stronger links with UBC activities, particularly with teaching and curriculum development, than industry does.

The university’s core tasks have long been teaching and research. They are mainstream activities, a natural and integral part of university's strategic mission. However, within the last decade, there is a clear shift towards furthering the university's mission. The so-called 'Third Mission' is related to integrating research valorisation and exploitation into its more traditional tasks of educating students and conducting basic research [14,15]. Interdisciplinary nature is another important feature of modern university education when distinct boundaries between disciplines tend to be erased. For instance, biology is often complemented by engineering biology, molecular design and synthetic biology; Stanford University even offers a new major in bioengineering to train students "at the interface of life sciences and engineering" [16]. Chemistry is widely associated nowadays with Green Chemistry which is a blend of biology, chemistry, and environmental science [17]. More than anything, computer science subjects have long become prerequisites to the digital literacy.

\section{Research and development $(\mathrm{R} \& \mathrm{D}$, also known as contract research, commissioned research, (inter)national projects, commercialized $R \& D)$.}

Cooperation in research and development $(\mathrm{R} \& \mathrm{D})$ is considered to be the most developed activity followed by education, especially student mobility [12, 18]. Higher education institutions (HEIs) offer benefit to the business sector for innovation with a longer-term horizon as well as shorter-term problem solving with direct applicability in the company. At the same time, business offers HEIs insights, opportunities, and cutting-edge data for high quality research [12].

The size of a company affects its R \& D involvement. Micro companies, per say, hardly ever participate in R\&D activities. An interesting fact specific to Europe is that most large enterprises cooperating with HEIs in R\&D, also cooperate with other businesses or have their own R\&D capability [12]. In other words, they do not regard universities as R\&D centres and do not expect universities to only conduct research. This trend may explain why there is, overall, a relatively small number of joint initiatives and projects, including R\&D and knowledge transfer, among European countries.

Another possible explanation for the low UBC engagement among European countries is a companies' narrow understanding of research. They are primarily interested in commercializing research results [13]. Quite often, the business sector gets involved into collaborative research activities to develop or refine a particular process or product. To them, R\&D is a business transaction with a specific goal to be achieved [13]. From enterprises' perspective, HEIs are a primary source of highly qualified workforce that can meet their business needs. Moreover, they consider research a potential way of improving their employees' qualifications [13]. At the same time, companies' innovative capacity can be boosted through research.

There are many diverse UBC modes or activities. The literature commonly refers to five of them: 1) R\&D; 2) academic mobility; 3) student mobility; 4) curriculum development and delivery; and 5) lifelong learning. While most HEIs and enterprises collaborate - first and foremost - in research, each has their own mixture of UBC activities unique to them and responsive to their goals and needs [12]. Despite their close connectivity in theory, in practice all five collaborative research activities demonstrate different effects with UBC drivers, barriers, and organizational characteristics [18].

\section{Mobility of academic staff (their research or training in the business sector).}

Yet enterprises are less interested in involving academics in business processes [18] and from their perspective, mobility of academics is the least common mode of cooperation. Staff mobility is generally limited to professors seeking employment outside academia. Furthermore, universities do not see mobility of academics in terms of their training in the world of business as equally important as, for instance, student mobility.

Student mobility (traineeships, internships, graduate placement, direct recruitment, research projects, seminars, scholarship programs, practical workshops, etc.).

The mobility of students is mainly related to larger companies [18]. Enterprises want to provide graduates with work experience and recruitment, thus, contributing to them directly developing core competencies. The highest value is assigned to traineeships and internships, especially in the industry sector [13]. Such a strong emphasis on internships also has to do with the curriculum itself since internships are compulsory in professional education [13].

Most often, enterprises cooperate with university career centres, teaching and research activities, and alumni networks. 
Through these channels, companies can offer students internship programs and soft skills courses (communication, problem solving, leadership, etc.). It is not uncommon when a career office organizes an event at the university where companies present themselves. For instance, a Bulgarian marketing company presents their concepts in online marketing at different career office events. It can motivate students to pursue careers in this domain. After such events, inspired student often contact the company; the company, in return, offers them internships.

Another way for students to get information on internships and companies' newly launched training programs is directly from their professors and academic boards. Trainees are selected upon them meeting certain inclusion criteria. In Europe, career fairs are also very popular during which leading companies advertise their upcoming internships. Sometimes companies organize practical workshops at the university premises. They can assess students' level of knowledge, their potential and select the most dedicated ones as trainees and, possibly, as potential employees. Following practical workshops, selected students are invited to attend interviews and submit their resumes and applications.

As a communication channel, traineeships and internships are extremely important as it is through them that enterprises eventually hire new graduates. Although enterprises advertise their job opportunities in many ways (for example, private or public agencies, the internet), they still rely on their personal contacts for hiring employees [13]. It is particularly true for micro companies in which the most popular recruitment mechanism remains to be personal contacts. From the company's perspective, the main goal of an internship is to prepare a student to work independently after a month of training in the job. In most cases, the internship period is divided among different departments so that trainees spend an allocated amount of time in each department and to know the company's operations as a whole unit. It is a holistic approach that is very similar to medical school training when students and residents are rotated among different specialties to familiarize themselves with different body systems. The goal of preparing a student to work independently can be achieved through regular hands-on exposures to real-life work when a student acquires necessary skills and develop competencies. It is an absolute benefit of internship. Since by its nature the internship is about attracting potential workforce into the company, the company automatically employs the best students at the end of internship.

When being asked about the degree of graduates' preparedness for the position they are about to be hired for in the company, most employers acknowledge a high level of theoretical knowledge demonstrated by new graduates. However, young professionals often lack transferable skills. The world of business is convinced that such skills as team leadership, resilience, time management and creativity are crucial for student employability. These skills are important to companies as potential employers and they are willing to cooperate with universities in order to enhance this set of skills in students.

Skill-wise, how prepared are recent graduates for the jobs they are being recruited for?

\section{Curriculum co-development, review, update and delivery (including trainings, joint course development, university lectures, practical teaching, development of degree programs, etc.).}

UBC can help align curricula and the skills of graduates with the labour market, improving employment pathways for students, and recruitment for employers as well as lifelong learning programmes for business [12]. The curriculum development and delivery are also mainly related to large and medium-sized companies when experts from the business world participate in HE. It is a so-called 'size effect' [12], with larger HEIs and businesses cooperating more in UBC areas with a longer-term payoff such as education. Business representatives attend career fairs and work closely with career centres to fill their vacancies. Large and medium-sized companies are far more involved into curriculum development and implementation and development of trainings (for instance, offering short training courses) than small private organizations do.

The extent of this UBC mode depends on how engaged enterprises are in career offices, alumni networks, and teaching and research activities. Participation in innovation departments also determines this cooperation mode, but its effect is about four times less [18]. Although businesses are generally less interested in actively developing curriculum (company-delivered courses are rare), guest lectures are common. Universities invite company representatives to give lectures or organize presentations on specific topics.

Since companies consider HEIs a primary source of highly qualified workforce, they are willing to participate in curriculum development and graduate transition to the labour market. The biggest internal barrier for them, however, is slow procedures of curriculum amendment. The business world is developing too fast and the academic world is too conservative in order for them to speak the same language. The dissonating result is as such: the two partners speak different languages in their pursuit of different goals. The dissonating result is also that educators and employers operate in "parallel universes", with young graduates inhabiting a world of their own [19]. According to McKinsey’s report [19], there is an astounding discrepancy between what HEIs think a new graduate should know to find a job and how employers and students themselves think about it. Specifically, 74 per cent of HEI providers are confident that the current university curriculum meets the market needs, while only 35 to 38 per cent of employers and graduates share the same sentiments.

Specifically for students with automation as a major, it is difficult to connect multiple technical courses they take and to envision a broader picture of how they fit into their specialty. That is why students find it challenging to choose elective courses when the time comes to do so among the options being offered to them. They decide on a course based on its popularity among other students (peer pressure) or do so intuitively rather than making an informed decision. However, it is not exclusively students' problem. While designing courses, educators provide their rationale in writing why they think these are important courses for them to teach and for students to take. However, educators do not always explain to their students how a particular course is integrated into the specialized training and why it is of value. There are some instructors who are deeply into the science they are doing and its theoretical premises that they disregard the practical component of the courses 
they teach. As a result, graduates are hesitant (if not pessimistic) about the value of some of the courses they have taken for their future employment.

To collapse these "parallel universes' of theory-oriented HEIs and real-life industry, the prevailing debates are around the extent to which universities should adjust their curricula to the market. Should they preserve their traditional role of training specialists for lifelong careers or become business-supporting units [18]? Should HE shift towards being more practiceoriented? What are the boundaries of such a shift? What is the employer's role in the development of graduates' competencies? Practical body of knowledge accumulated by enterprises can complement formal university education that is otherwise solely theory-driven. Practical training and knowledge is particularly important for the world of business as opposed to "the exaggerated theoretical knowledge” offered by the university curriculum [13, p. 37).

The key question remaining open is whether and in what way the academic teaching style is suitable for training in companies. If it is truly compatible with and beneficiary for the business world, then enterprises should overcome their existing prejudices against HE. The HE curriculum should stay separate from the business world and, as such, governed traditionally as it has always been. If the academics' approach cannot meaningfully contribute to the professional knowledge, then several options can be contemplated. The first option is to create standards for such capabilities development. The alternative option is for practitioners to engage - more formally and actively - into HE professional training. Along these lines, it is worth considering the development of national qualification tools [18].

We strongly believe that HE should be highly sensitive to the demands of a knowledge-based society, in general, and to the business needs, in particular. University courses in computer engineering, automation and computer-integrated technologies should be revised and updated at least once every two years (if not more often). In response to scientific innovations and labour market changes, new courses should be designed and offered both to students and the academia. It is also worth inviting field experts to co-design and co-deliver upgraded courses. This allows to augment personal relationships between the academia and business and stimulate further experience exchange between the two. The experience exchange is particulalrly valuable as it gives an opportunity of looking at the same task or problem from two distinct perspectives. As a result, future UBC findings and innovations can become richer, more encompassing and potentially more generalizable for other fields of knowledge and practice.

Universities should open up their communication channels with students and employers (as they are affected the most by university activities) and with the society at large. This will likely lead to a massive reconstruction of HEIs. As Epure [11] succinctly put it, the process should start at the top (among academics), not at the bottom (at industry-specific workplaces). Universities should conduct a broad range of industry-specific surveys among enterprises to get a clearer understanding of what skills employers cherish as essential for their work. The findings will largely inform the design of course load and its modes of delivery.

What is evident even at an early stage of European UBC development is the necessity to reconceptualize HE as such. And the onus is on HEIs as they need to embrace a shift from patent and knowledge transfer to a lifelong process of developing competencies. From the enterprises' perspectives, the business world has always been practice- and profit-oriented. Entrepreneurs value a toolkit of skills, attitudes and competencies that are key for tackling their specific goals. They are not interested in investing - financially, resource- and timewise - in the existing body of theoretical knowledge that does not apply to them. Employers want to see tangible outcomes of business processes. The process of knowledge acquisition and dissemination for the sake of knowledge does not appeal to them. However, the opposite is true for universities with their focus on production of theoretical knowledge.

Lifelong learning (including adult education, short courses and training).

The last UBC mode is lifelong learning, including adult education. Similar to curriculum development, this mode is determined by structures and approaches that are related to competencies development and engagement in innovation departments [18]. The literature indicates that lifelong learning activities correlate negatively with enterprises' experience of how flexible HEIs are. These days there exist so many alternative pathways (double or dual major study degrees, virtual learning, reverse mentoring, internships, part-time studies, etc.) that the leading role of university as a learning venue can be easily lost. UBC has permanently changed the perspective of modern higher education. UBC itself has outgrown the narrow boundaries of patent transfer into a process of competencies development as far as specific entrepreneurial skills and attitudes are concerned [20].

\section{Government support for UBC.}

There are different forms of government support with different longevity - from direct program spending and subsidies to fiscal (tax credits) and government research incentives. Tax credits can apply to a wide range of expenditures - from materials and supplies, salary and contract payments to capital expenditures and leases. What is important for the company is that unused tax credits can be carried back a specified number of taxation years and forward, also a specified number of taxation years. The government can offer accelerated $100 \%$ write-offs for eligible equipment.

For tax-based incentives, the government would want to see that SMEs increase the total amount of R\&D investments. Companies can still allocate their funding between external (with university involvement) and internal (in-house) R\&D activities based on what makes the most business sense [21]. However, little is known about the direct impact of tax-based incentives on UBC [21]. There is some risk that SMEs substitute internal R\&D expenditures with external R\&D investments.

With its programs for UBC support, the government aims at meeting several policy objectives, namely: 1) to encourage the private sector, especially small businesses, to pursue R\&D activities; 2) to provide incentives of immediate benefit; 3) to 
provide incentives that are simple to qualify for. Unfortunately, it is not enough for the government to make UBC a policy priority. Government agencies must also measure UBC progress and report it transparently to the general public.

Taking the partnership forward: UBC drivers.

When universities and their corporate partners decide to participate in UBC, they do not do so in isolation from the regional, national and even international contexts they are embedded into. In the literature, the notion of regional context is defined differently but usually spans over an administrative or territorial same-country region to a cross-border region [10]. The region can be well established in terms of UBC, with a high level of integration developed over many years. There might be strong regional coverage with networks for research commercialization. Or it can be that the business sector and the academics are at early stages of sparking UBC opportunities and supporting its long-term sustainability. In the first case scenario, the role of government is usually substantial, with regional and national support policies and public funding in place. Scientific and industrial hubs in the regions have also shown to contribute positively to UBC development [10].

It is also worth noting that UBC is likely to take place in specific economic sectors rather than others [21]. This trend alone has its implications: instead of promoting UBC across all the sectors, it is best to focus on those with market opportunity and business interest. But it does not negate the necessity of maintaining basic and fundamental research at a university level.

Mutual motivations are important drivers to strengthening collaborative links between universities and private companies. Among the key motivations, both from academic and business perspectives, are professionalization of human resources, increased competitiveness, exploitation of research and service to society. However, businesses and universities tend to have different motivations for UBC. The multiple surveys conducted in the UK, Australia, Canada and the US demonstrate that the business sector is mostly interested in gaining access to university facilities and talents. Increasing profitability is not among their top priorities [21]. Businesses consider university long-term orientation to research when projects have long time frames, as a barrier to cooperation.

At the current stage of UBC development in the Ukraine characterized by no or very minimal government support of UBC, we see three possible scenarios of taking partnership in automation further for the Ukrainian small and medium-sized enterprises. Our focus is on small and medium-sized business since the literature indicates that companies of these sizes barely or insufficiently participate in UBC activities. However, the literature indicates that company size is not a reliable predictor for innovation. Due to their greater profit margin, large companies spend more on R\&D. Moreover, when allocating their R\&D investments, large enterprises fully account for the presence of and access to leading universities. That having been said, it does not mean that SMEs are intrinsically less innovative [21].

Scenario 1: SMEs have no or limited R\&D capacity of their own and would like to gain exposure and access to academic expertise on automation, for example, data analytics. As an inherently digital field, automation requires new combinations of skills that are complementary to the company's own competencies [22]. SMEs can also be interested in increasing their market competitiveness by developing new or improving existing automation technologies. Sometimes, SMEs are faced with industrial, real-life challenges and explore solutions that academics with complementary skills and a richer pool of expertise might provide them with. SMEs place task-specific orders with universities, whether they be R\&D-related activities and/or employees' training. SMEs fully fund projects. As high-profile institutions, universities, on the other hand, are responsible for testing all the findings on their or other organizations' premises, if needed.

If automation transfer activities are effective for SMEs, universities provide training to SMEs' personnel to ensure that their innovations can be successfully applied on the company premises. Universities also provide an ongoing technical assistance to the company as part of their UBC agreement. It can take a form of consultancy services provided by academic researchers to their business partners or other external enterprises. This allows to continuously improve professionalization of human resources on both ends. The faculty are given multiple opportunities to immerge themselves into cutting-edge, real-life research questions. Both parties have more opportunities to use each other's institutional data as well as research and industrial facilities. As a consequence of collaborative work, new research topics arise; new research ideas are generated; and follow-up research projects are planned. There is a clear increase in such research outputs as joint patents, doctoral degrees awarded and $\mathrm{PhD}$ thesis publications as well as conference and journal papers. In other words, further fruitful and sustainable collaboration is likely to happen.

Scenario 2: The university and the company develop a collaborative research project together. The project is fully funded by the company that is much more involved into it than in the first scenario. Commitment and interdependence are key words here; it is a very intensive and dense involvement on both ends. This may include sharing tasks and responsibilities, overcoming challenges as well as acknowledging partner's input into the success. The company might have some interim, practice-based results that need to be further elaborated on. It is true that the company is interested in strengthening its $R \& D$ capacity while the university gets an additional source of funding. The company seeks maximum implementation of research results in its industrial processes and on its premises. As long as partners are dedicated to building trustful relationship, some divergence in their goals should not be a problem.

Scenario 3: Academia has ready-to-use innovative products, licenced patents and automation technologies that they are willing to offer to SMEs in exchange for: 1) some funding; and 2) an opportunity for students and faculty to use company's premises and automation equipment for internships. Academia gets access to industrial expertise while the business sector gets a lot of exposure to specialized scientific knowledge. Both partners benefit from organizational and personal networks made available to them [10].

The third scenario is an antipode to the notorious "European paradox". European countries (and the Ukraine is not an 
exclusion from the list) are accused of failing to implement scientific innovations into practice. Scenario 3 does exactly the opposite - it implements patented innovations and cutting-edge, interdisciplinary research into industry.

Regardless of the scenario chosen, universities and businesses are often driven by exploitation of research and service to society as part of their organizational strategy. Service to society, as elevated as it might be first perceived, is about training highly qualified specialists, on both ends, and facilitating industrial processes through automation, on business end. As a result of UBC activities completed through the three pathways, SMEs are able to economically exploit research. At the same time, universities are able to attract more funding from diversified sources rather than being completely dependent on government financing. This allows to secure steady financial flow for medium- and long-term research projects. Ensuring continuous funding is particularly important for academia as it has been a challenge for some universities [10]. To cope with it, they actively seek opportunities to broaden their funding sources.

Increased competitiveness applies to both, too. After successful collaborative research, universities become more reputable and, therefore, more visible to other stakeholders. Common activities between the university and the company attract more prospective students who then apply to the particular university. It is particularly important for universities who compete for students nowadays. Once the university reptation is built up, new companies are more willing to engage into collaborative research activities. Other universities start considering UBC opportunities as well.

Conclusion. Both parties - universities and businesses - recognize the importance of cooperation. However, companies do not rely on UBC as a major source of their workforce and innovative business processes. Companies are focused on their shortterm benefits and expect tangible, profit-bringing results (for example, a better return on investment in R\&D). The business is always preoccupied with the benefit of a project, i. e., why it is good for them. Universities, conversely, are more interested in strategic planning and long-term goals; they are wondering about new results and want to publish confidential data [13]. The lack of shared values and mutual interests as well as different time horizons can make UBC problematic. This trend indicates that universities still have a long way to go before they can meet the needs of their business partners. Efficient and effective partnerships can only be based on common interests and shared ideas with added value for both partners. They should jointly own the results of their success (along the five UBC activities) and share responsibility for their failures. Some SMEs do not want to work with universities because they fail to see the added value of such cooperation. Universities need to be persuasive about UBC benefits, and this task alone turns out as a challenge.

\section{References}

[1] Matthews, A., McLinden, M., \& Greenway, C. (2021). Rising to the pedagogical challenges of the Fourth Industrial Age in the university of the future: an integrated model of scholarship. Higher Education Pedagogies, 6(1), 1-21. https://doi.org/10.1080/23752696.2020.1866440

[2] Schwab, K. (2017). The fourth industrial revolution (First U.S. ed.). New York: Crown Business.

[3] Seldon, A., \& Abidoye, O. (2018). The fourth education revolution: Will artificial intelligence liberate or infantilise humanity. Buckingham: The University of Buckingham Press.

[4] T.E. Duncan, B. Pasik-Duncan: Adaptive control of continuous time stochastic systems, J. Adapt. Control Signal Process. 16, 327-340 (2002). https://doi.org/10.1002/acs.712

[5] E.L. Boyer: Scholarship Reconsidered: Priorities of the Professoriate (Princeton Univ. Press, Lawrenceville 1990).

[6] Peters, M.A., Jandrić, P., \& Means, A.J. (eds.). (2019). Education and technological unemployment. Singapore: Springer Singapore. https://doi.org/10.1007/978-981-13-6225-5

[7] Stanford2025, "Learning and Living at Stanford - An Exploration of Undergraduate Experiences in the Future," June 01, 2013, http://www.stanford2025.com.

[8] Penprase, B. E. (2018). The fourth industrial revolution and higher education. Higher education in the era of the fourth industrial revolution (Ed. Nancy W. Gleason), p. 207. https://doi.org/10.1007/978-981-13-0194-0_9

[9] Aoun, Robot-Proof: Higher Education in the Age of Artificial Intelligence (Cambridge: MIT Press, 2017), 69. https://doi.org/10.7551/mitpress/11456.001.0001

[10] Borrell-Damian, L., Morais, R., \& Smith, J. H. (2014). University-business Collaborative Research: goals, outcomes and new assessment tools The EUIMA Collaborative Research Project Report.

[11] Epure, M. (2017, July). University-business cooperation: adapting the curriculum and educational package to labor market requirements. In Proceedings of the International Conference on Business Excellence (Vol. 11, No. 1, pp. 339349). Sciendo. https://doi.org/10.1515/picbe-2017-0036

[12] Davey, T., Meerman, A., Galan Muros, V., Orazbayeva, B., \& Baaken, T. (2018): The State of University- Business Cooperation in Europe. Executive Summary. Accessed: July 10, 2021.

[13] Andreeva, G., Paunova, N., Verger, R. F., Simán, E., Bąk, M., Buze, A., ... \& Calero, M. V. (2015). Emerging Modes of Cooperation between Private Sector Organisations and Universities.

[14] Compagnucci, L., \& Spigarelli, F. (2020). The Third Mission of the university: A systematic literature review on potentials and constraints. Technological Forecasting and Social Change, 161, 120284. https://doi.org/10.1016/j.techfore.2020.120284

[15] Perkmann, M., Tartari, V., McKelvey, M., Autio, E., Broström, A., D’este, P., ... \& Sobrero, M. (2013). Academic engagement and commercialisation: A review of the literature on university-industry relations. Research policy, 42(2), 423-442. https://doi.org/10.1016/j.respol.2012.09.007 
[16] Tom Abate, “New Bioengineering Major culminated department’s evolution,” October 22, 2015, https://engineering.stanford.edu/news/new-bioengineering-major-culminateddepartment-s-evolution.

[17] Mammino, L., \& Zunin, V. G. (2015). Worldwide trends in green chemistry education Cambridge, UK: Royal Society of Chemistry.

[18] Pavlin, S. (2016). Considering university-business cooperation modes from the perspective of enterprises. European journal of education, 51(1), 25-39. https://doi.org/10.1111/ejed.12163

[19] McKinsey Center for Government (2012). Education to employment: Getting Europe's youth into work. http://www.mckinsey.com/insights/social sector/converting_education_to_employment_in_europe.

[20] Rudawska, I., \& Kowalik, J. (2019). Towards university-business cooperation: Key drivers, barriers and modes. International Entrepreneurship Review, 5(2), 91-105. https://doi.org/10.15678/IER.2019.0502.06

[21] Government policies to encourage university-business research collaboration in Canada: Lessons from the US, the UK and Australia (2011).

[22] OECD. (2019). University-Industry Collaboration New Evidence and Policy Options. OECD Publishing.

Отримана в редакції 06.07.2021. Прийнята до друку 23.08.2021. Received 06 July 2021. Approved Approved 23

August 2021. Available in Internet 31 September 2021.

УДК 528.94:378.015.311:378.091.212.2(477.74)

\title{
РОЗРОБКА ІНТЕРАКТИВНОЇ КАРТИ АБІТУРІСНТА ОДЕСИ
}

\author{
Науменко О.М. ${ }^{1}$, Мельник К.В. ${ }^{2}$, Попков Д.М. ${ }^{3}$ \\ 1,2,3 Одеська національна академія харчових технологій, Одеса, Україна \\ E-mail: ${ }^{1}$ naumenko.a.n.00@gmail.com, ${ }^{2}$ ksmelnikvl@gmail.com
}

Copyright (C) 2021 by author and the journal “Automation of technological and business - processes”. This work is licensed under the Creative Commons Attribution International License (CC BY). http://creativecommons.org/licanses/by/4.0
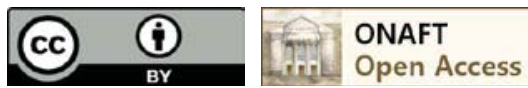

\section{DOI:}

Анотація. Дана робота присвячена розробиі веб-ресурсу, який автоматизує пошук інформації про заклади вищої освіти та вступу до них. Об'єктом дослідження виступають заклади вищої освіти та спеціалізації, які можна здобути абітурієнтам. Завданням проектування є розробка серверної частини веб-ресурсу, що взаємодіє з базою даних. Після дослідження основних проблем предметної області, аналізу аналогів та вибору засобів реалізації, було розроблено базу даних та функціонал веб-сайту. У якості системи управління базою даних було обрано MySQL з вебдодатком для ї̈ адміністрування Рhртуаdmіп. Для реалізації інтерфейсу було обрано мову гіпертекстової розмітки HTML, каскадні таблиці стилів CSS та фреймворк Воотstrap, щзо використовує сучасні напрацювання в області НTML mа CSS. Для написання функиій було обрано мову програмування РНP та скриптому мову JavaScript.

Наукова значимість розробки полягає у чіткій та детальній структуризації необхідної інформації щуодо закладів вищої освіти м.Одеси на єдиному інформаційному ресурсі. У результаті виконання роботи було створено веб-ресурс з картою абітурієнта Одеси, щзо відповідає всім вимогам для зберігання та структуризації інформації.

Даний веб-сайт підтримусться всіма сучасними браузерами, щяо робить його доступним усім користувачам мережі Інтернет.

Abstract. This work is devoted to the development of the web resource, which automates the search for information about higher education institutions and admission to them. The object of the study are institutions of higher education and specialization, which can be obtained by applicants. The task of design is to develop a server part of a web resource that interacts with the database. After researching the main problems of the subject area, analysis of analogues and the choice of means of implementation, a database and functionality of the website were developed. MySQL with a web application for its administration Phpmyadmin was chosen as the database management system. To implement the interface, the language of hypertext markup HTML, cascading tables of CSS styles were chosen and the Bootstrap framework, which uses modern developments in the field of HTML and CSS.. PHP programming language and JavaScript scripting language were chosen for writing functions. 